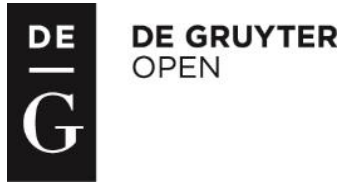

\author{
*Alina Bottez \\ Facultatea de Limbi si Literature Străine, \\ Universitatea București, Str. Edgar Quinet 5-7, \\ Sector 1, București, Romania \\ email: alina.bottez@1ls.unibuc.ro
}

\title{
RELIGION AND CULTURAL IDENTITY IN SHAKESPEARE'S ROMEO AND JULIET AND THE MUSICAL WORKS IT INSPIRED
}

\begin{abstract}
Protean Shakespeare thrives not only in the theatre, but also through what Bolter and Grusin call remediation. This article analyses the religious stances in the play and then shows how opera, symphony and musical have been adapting the veteran Elizabethan drama since the $18^{\text {th }}$ century. Its main approach is comparative and relies on the history of mentalities. Adaptation is dictated by cultural context, the conventions of the lyrical theatre, social and political factors, and reception. The confusing religious configuration of Shakespeare's England is reinterpreted kaleidoscopically. The article demonstrates, for instance, that Berlioz and Gounod reread it according to staunch Catholicism in $19^{\text {th }}$ century France, while Bernstein's West Side Story moves the action to New York in the mid50's, the Capulets and Montagues are replaced with rival Polish and Puerto Rican gangs and religion with cultural identity.
\end{abstract}

Keywords: opera, musical, religion, adaptation, cultural identity

Written around 1591-1595, Shakespeare's Romeo and Juliet bears the marks of the religious turmoil that England had witnessed since 1534, when Henry VIII veered Britain from Catholicism to Protestantism for personal reasons. After groping through that change, the nation was cleft by the rebellions against the Catholic Bloody Mary, who had her Anglican sister - daughter of Henry VIII and Ann Boleyn - locked in the Tower on suspicion of complicity with Sir Thomas Wyatt. The Elizabethan age seemed to be an age of religious tolerance and forgiveness, but the conflict between the English sovereign and Mary Stuart, Queen of Scots, had religious undertones as well. The accession to the throne of the Catholic James I only complicated matters further.

Shakespeare's spiritual affiliation has been a matter of hot debate for centuries. His faith in God is beyond question, and his Christianity is apparent, as is his lack of concern with any other religion, with the possible exception of Mosaism, represented by Shylock, Jessica and Tubal. But his interest in these characters is ethnic, cultural and moral rather than spiritual per se. In Othello, his references to "the turbaned Turk" and "the circumcised dog" are just that - cursory allusions to a

\footnotetext{
* Dr Alina Bottez is currently a Senior Lecturer with the English Department of the Faculty of Foreign Languages and Literatures of the University of Bucharest, specialising in Elizabethan and Victorian literature. She taught Singing at the National University of Music in Bucharest (2010-2015) and is also following a performing career in Romania and abroad, interpreting leading soprano roles. She was granted the Summa cum laude distinction for an interdisciplinary doctorate on Shakespeare's adaptations into opera in 2013 (cotutelle between the two universities) and for two years she had a programme on opera, its literary sources and cultural context on Radio România Muzical.
} 
remote, utterly exotic and undesirable religion. If he is interested in any creed outside Christianity, it is the pre-Christian layer of pagan beliefs and folk lore, on which he drew heavily.

The issue of denomination, however, is hardly equally clear. As Greenblatt shows at length in Will in the World (2005:89-116), Stratford became nominally Protestant in 1533, when Henry VIII decided to break with papality ${ }^{1}$. When Queen Elizabeth came to the throne, she at first suggested that she was more interested in obedience than in pure conviction, and most ordinary people retained their previous religious beliefs and loyalties. But in 1570, when Shakespeare was six, Elizabeth was excommunicated by the pope Pius V and persecutions started. In 1580, "Pope Gregory XIII proclaimed that the assassination of England's heretic queen would not be a mortal sin (...) - a clear licence to kill" (Greenblatt, 99).

John Shakespeare, the playwright's father, was a constable in 1558-1559 and had to preserve the peace between Catholics and Protestants. When he died, it seems he left "a piously Catholic 'spiritual testament', belying his public adherence to the Reformed faith" (Greenblatt, 101). William's mother, Mary, was related to one of the major Catholic families in the region. According to Greenblatt (102), as Will grew up, there was a split between his father (officially employed by the Protestant state) and his mother (in all probability a devout Catholic), as well as a split within his father (outwardly reformed, inwardly loyal to the pope).

In fact, the religious situation of the age turned the English into a nation of two-faced men and women, who preserved their inward Catholic belief while going along with the official denomination and displaying steadfast public adherence to it. The Mass was outlawed and parents sent their children "to distant neighborhoods, where they were less likely to be caught by the oppressive system" (Greenblatt, 100). It was the instinct to survive, but maybe also the determination of keeping both options open, of being prepared, of giving the benefit of the doubt and of seeing what both sides had to offer. Maybe this was the ancestor of Doublethinnk.

This cannot have helped things with Shakespeare's clarity and purity of spiritual convictions. Hamlet is the best proof of his blurred and amalgamated views on the matter: "If his father was both Catholic and Protestant, William Shakespeare was on his way to being neither" (Greenblatt, 113).

If Shakespeare's faith is obvious, so is his total disregard for dogmatic detail and accuracy, as well as his violent dislike of the Church as institution and men of the cloth as its representatives:

saints, Shakespeare understood all his life, were dangerous people. Or perhaps, rather, it would be better to say that Shakespeare did not entirely understand saints, and that what he did understand, he did not entirely like. In the huge panoply of characters in his plays, there are strikingly few who remotely qualify. (...) Nothing in his work suggests a deep admiration for the visible church" (Greenblatt, 110-111).

If he only ridicules Parson Evans in comic mode in The Merry Wives of Windsor, he blatantly incriminates Friar Laurence in his tragedy Romeo and Juliet, accusing him of criminal meddling.

Friar Laurence is a Franciscan monk. The fact that the action of the play takes place in Catholic Italy at the beginning of the fourteenth century does not make Shakespeare feel the need for any rigour when it comes to religious references. However, Friar Laurence does invoke St. Francis twice (II, 2, 65 and V, 3, 80²), and Friar John does talk about barefoot brothers V, 2, 5. But, as always, Shakespeare is interested in Laurence's moral profile, not in his ecclesiastic nexus, showing that the latter in no way influences the former.

In II, 2, Romeo informs the audience that Friar Laurence used to chide him for loving Rosaline, and the monk's vehement sermon against the young man's fickleness and inconstancy can be witnessed by the public directly. But as soon as he hears that the object of Montague's love is now Capulet's daughter, he undergoes a volte-face: "In one respect I'll thy assistant be; / For this alliance may so happy prove, / To turn your households' rancour to pure love" (II, 2, 90-92). Deceitful as ever, Shakespeare makes the monk appear to have only the two lovers' well-being at heart, meaning to unite them and put an end to their families' longstanding feud. However, he is animated by ambition

\footnotetext{
${ }^{1}$ After he had fiercely attacked Luther and been declared "Defender of the Faith" by the Pope in 1520.

${ }^{2}$ Eliminated by Jill L. Levenson in the 2008 Oxford World's Classics edition.
} 
and mundane interests, wishing to take credit for his accomplishment and be rewarded for his politic mediation. The whole evolution of the character supports this theory.

First of all, Friar Laurence distrusts all possibility of spiritual connection between people in love. When hearing that Romeo has not slept in his bed, he exclaims: "God pardon sin! Wast thou with Rosaline?" (II, 2, 44) He is quick to suspect carnal sin, even if he has been privy to Romeo's frustration at unrequited love. In the same second scene of Act II, he comments on love: "Young men's love then lies / Not in their hearts, but in their eyes" (II, 2, 67-68), and the implication is, of course, that it lies much lower than that, as Romeo and Juliet is one of Shakespeare's bawdiest plays and the good friar contributes his fair share to this ${ }^{3}$ (as does the pun on 'to lie').

In II, 5, Laurence advises Romeo: "love moderately" (14), thus proving his complete ignorance of the feeling. However, before marrying Romeo and Juliet, he tells them: "For, by your leaves, you shall not stay alone / Till holy church incorporate two in one" (II, 5, 36-37), proving to grasp quite well the notion of physical attraction and meaning to prevent any risk of sinful coitus.

In the same scene, he refers to marriage as "this holy act" (1), but when getting ready to officiate, he tells the bride and groom "Come, come with me, and we will make short work" (II, 5, 35), showing plainly that he attaches no great weight to this paramount event in their lives and makes no attempt to make it memorable. Accordingly, the wedding is not shown on stage.

The monk seems to share Shakespeare's bad opinion of women to a certain extent. In II, 2, he sententiously pronounces: "Women may fall, when there's no strength in men" (II, 2, 80), thus granting them no moral stamina and independence whatsoever and branding them as weak from the start.

In II, 5, as Juliet approaches his cell, he comments: "Here comes the lady: O, so light a foot / Will ne'er wear out the everlasting flint: / A lover may bestride the gossamer / That idles in the wanton summer air, / And yet not fall; so light is vanity" (II, 5, 16-20), clearly placing the equality sign between Juliet (or women in general) and vanity.

In $\mathrm{V}, 2,25$, the friar is full of apprehension that the eager wife, returning from her deathlike slumber, will "beshrew" him much for his failing to convey the letter to Romeo. Since to beshrew means to curse or invoke evil upon someone, this prospect does not cast too favourable a light on the monk's opinion of Juliet. Likewise, when young Montague has been banished for killing Tybalt, Laurence observes: "Thou art wedded to calamity" (III, 3, 3). At face value, this voices the idea that Romeo attracts disaster, but the way it is expressed in words cannot be accidental. Since Romeo has been wedded to Juliet for only a few hours, this identifies her with calamity.

Similarly, the greatest insult that Laurence can think of is calling Romeo a woman: "Art thou a man? thy form cries out thou art: / Thy tears are womanish; thy wild acts denote / The unreasonable fury of a beast: / Unseemly woman in a seeming man!" (III, 3, 108-111), subtly associating not only tears of weakness with womanhood, but also wildness, fury and the term "beast".

The friar's most Christian intervention throughout the play is his discourse against ingratitude, selfishness and suicide in III, 3: "O deadly sin! O rude unthankfulness! (...) Hast thou slain Tybalt? wilt thou slay thyself, / And slay thy lady, that in thy life lives, / By doing damnèd hate upon thyself? (...) Thy dear love sworn but hollow perjury, / Killing that love which thou hast vow'd to cherish" (III, 3, 24; 115-117; 127-128).

It is interesting to note that the monk does not really reprimand Romeo for killing his fellow human being, Tybalt, quickly dismissing this as an act of self-defence, just like Juliet: "Tybalt would kill thee, / But thou slew'st Tybalt" (III, 3, 136-137). He is far more set against the young man's intent to commit suicide, which he calls "doing damnèd hate upon thyself" (III, 3, 117). In the same speech, he reveals to Romeo what his blessings are and, consequently, what his reasons to be thankful are excellent points that are central to the Christian faith.

However, this is bathetically followed by his dispatching Montague to consummate his wedding and sending the Nurse with a message to Juliet which advises her to lie and to deceive: she is to "hasten all the house to bed" (III, 3, 155) in order to facilitate Romeo's access, preying on the family's grief at losing Tybalt.

\footnotetext{
${ }^{3}$ Shocking as it may seem, Friar Laurence shares this obsession with carnal lust with Iago, even if in a much more subdued and less pathological way.
} 
If up to this point Friar Laurence's behaviour can only be blamed for a certain amount of worldliness, with Act IV it becomes reprovable. The first scene brings him together with Paris, the county chosen by the Capulets to marry Juliet. The nobleman goes to him in order to arrange the coming wedding, which would be the perfect moment for the friar to shed light on Juliet's union to Romeo. Such disclosure would prevent any further plans of marriage, it would grant an entirely different status to Juliet, acknowledgeable both by the Church and by society, and it would force the two feuding families to come to terms and maybe even the Prince to pardon the exile. But the uproar would indeed be quite great and Laurence would be held accountable. Therefore, out of sheer cowardice and self-interest, he keeps quiet and does nothing to illuminate Paris. The only thing to which he objects is that he does not know whether the bride has agreed to the wedding or not, which is downright mendacious.

Left alone with Juliet, the monk amazes the audience by saying "Ah, Juliet, I already know thy grief; / It strains me past the compass of my wits: / I hear thou must, and nothing may prorogue it, / On Thursday next be married to this County" (IV, 1, 46-49). The pathos in his discourse may trick the public into believing this inexorable doom, but the truth is that one word from him averring the legitimacy of Juliet's marriage to Romeo would instantly put an end to Paris's claim, not only proroguing (postponing) the wedding, but cancelling it altogether. Since as a clergyman he cannot condone bigamy, his solution is deceit, and of the cruellest kind: to let everybody believe that a fourteen-year old girl is dead. He sends Juliet off with further advice of mendacity, as he encourages her to go home and "give consent / To marry Paris" (IV, 1, 89-90).

When faced with the disconsolate bereaved family, he gives a particularly heartless speech on the bliss of the dead and on how reason shows us that we should be happy when someone dies and is reunited with God - knowing all along that Juliet is alive. Far from taking this new opportunity to tell the truth, at the end of the scene, he is quite hypocritical, covertly blaming them for Juliet's death: "The heavens do lour upon you for some ill" (IV, 4, 120). This directly contradicts his previous speech, as it presents the death of a loved one as punishment for the family, not as bliss for the deserving departed, therefore as retribution, not as reward. He manipulates them subliminally, making them think of the discord with the Montagues, as well as of their having forced their child into an unwanted marriage, as possible reasons for their plight.

Even when he finds out that Juliet will awake without Romeo at her side (since he has not received his letter), his solution is to break into the crypt with a crowbar, snatch Juliet's body and keep her at his cell until her husband's return, leaving her family think her grave has been robbed! (V, $3,23-8)$

Going to the crypt, his "mind presages ill" $(\mathrm{V}, 3,93)$ and he is overwhelmed with the foreboding of "some ill unthrifty thing" (V, 3, 136), which is superstitious and not very Christian. But when he finds Romeo dead and Juliet awake, his reaction is outrageous not only from a Christian point of view, but from a moral one in general. Again refraining from telling the truth, his advice is: "Come, I'll dispose of thee / Among a sisterhood of holy nuns: / Stay not to question, for the watch is coming" (V, 3, 156-158). By meaning to conceal her sine die, perhaps even for the rest of her natural life, he unequivocally proves that he would rather leave a whole family distraught at the loss of a child than admit to his mistakes and give her back to her family; he also shows that he does not hesitate to cloister a fourteen-year old girl, who might still have her whole life ahead of her. With both Romeo and Paris dead, Juliet - heartbroken as she is - is nonetheless out of all danger and no harm could come to her on revealing that she is alive. So Friar Laurence, unencumbered by any hint of fellowfeeling, only thinks of protecting himself.

However, his cowardice reaches the apex when, upon Juliet's refusal to follow him, he flees the scene, unconcerned with her fate and her state of mind. Thus, if he is only indirectly responsible for the death of Romeo and Paris, he is directly responsible for Juliet's. Shakespeare's typical way of casting doubt makes us wonder if the friar does not actually want the girl to kill herself, so that he should be able to explain the tragic outcome unchallenged.

At the end, Friar Laurence repents, but so deftly as to exonerate himself: he calls the fatal entanglement "this work of heaven" $(\mathrm{V}, 3,261)$, blaming it on God, not on his own fear to tell the truth. When telling the story, he relates that he left the tomb scared away by a noise. Since the

\footnotetext{
${ }^{4}$ Harmful - editor's no. 136, Shakespeare, Romeo, p. 346. In other editions - "unlucky".
} 
audience has already witnessed the scene, an attentive spectator can immediately detect the lie. Finally, he seems disposed to accept punishment: "if aught in this / Miscarried by my fault, let my old life / Be sacrificed" (V, 3, 266-268). But he handles his words so adroitly as to clearly imply that none of it is his fault. Consequently, the Prince replies "We still have known thee for a holy man" (V, 3, 270), which is quite ambiguous. The adverb "still" indicates that his being a clergyman is not in itself proof of innocence, since the Prince feels the need to corroborate his testimony with that of Romeo's manservant and with the letter written by the monk, but it does cast reasonable doubt on his being a villain $^{5}$. In the end, he is absolved of all his guilt.

If Friar Laurence, who should be the bearer of spirituality in the play, is motivated by mundane pride, the Nurse is completely amoral. She sees Juliet's marriage to Romeo as no impediment to her marriage to Paris at all, not being burdened with God's commandments or Church dogma on bigamy.

The two lovers have interesting reactions to religion. As Greenblatt remarks, "the only sainthood in which Shakespeare seems passionately to have believed throughout his life derives precisely from the subject matter that Campion ${ }^{6}$ wished his students to avoid: erotic sainthood" (111).

Romeo does not seem to give religion a second thought. But he is smitten with the sacred aura of Juliet's virginity, "the mystery of virginity that attracts, confuses, and bedevils many of the male characters in Shakespeare's plays, the fetishized commodity that is and is not" (Carroll, 2001:28). He proposes to Juliet (by proxy) a few hours after having met her. However, in II, 2, he does ask for "holy marriage" (61), and in scene 5 he refers to the ceremony as "holy words" (6). In general, when he uses words that refer to divinity, he redirects them to his exalted lay love. Thus, heaven is where Juliet lives and banishment is "Purgatory, torture, hell itself" (III, 3, 18). The mention of Purgatory is a hint at Catholicism, but its equation with hell proves Shakespeare's blurred conception on the matter. To him, earthly love is sacred, and divinity is also associated with the profane, since "every cat and dog" (III, 3, 30) can live in Juliet's heaven. Romeo is quick to kill Tybalt and also talks easily about killing himself, thus not being greatly concerned with the infringement of the fifth commandment.

Juliet is very different from her bridegroom and her mind is much more pragmatic. Throughout the play, she builds an extended metaphor in which she pairs off love (or marriage) with material wealth, which is a very Protestant, Puritan approach:

Conceit, more rich in matter than in words, Brags of his substance, not of ornament:

They are but beggars that can count their worth;

But my true love is grown to such excess

I cannot sum up sum of half my wealth.

(II, 5, 30-34)

$\mathrm{O}$, I have bought the mansion of a love,

But not possess'd it, and, though I am sold,

Not yet enjoy'd.

(III, 2, 26-28)

And when she thinks Romeo is dead, she calls her heart "this poor bankrupt" (III, 2, 57).

Like Romeo, she also mixes divine and earthly love. When talking of her husband as of her cousin's slayer, she gives him various oxymoronic names associated with spirituality: "Fiend angelical" (III, 2, 73), "Dove-feathered raven" (III, 2, 76), "Despisèd substance of divinest show" (III, 2, 77), "A damnèd saint" (III, 2, 79), "O nature, what hadst thou to do in hell, / When thou didst bower the spirit of a fiend / In moral paradise of such sweet flesh?" (III, 2, 80-82)

Still like Romeo, she too elevates desire to the intensity of ecstasy and, as Davis contends, "The play personalizes desire in ways which constantly alternate between idealism and failure

\footnotetext{
${ }^{5} \mathrm{Cf}$. IV, 3, 23-28: "What if it be a poison, which the friar / Subtly hath minister'd to have me dead, / Lest in this marriage he should be dishonour'd, / Because he married me before to Romeo? / I fear it is, and yet methinks it should not, / For he hath still been tried a holy man" (Juliet).

${ }^{6}$ Edmund Campion (1540-1581) was an English Roman Catholic Jesuit priest and martyr arrested by priest hunters, convicted of high treason, hanged, drawn and quartered at Tyburn, beatified by Pope Leo XIII in 1886 and canonised in 1970 by Pope Paul VI. Greenblatt speculates he may have met Shakespeare.
} 
(2001:45). But this is not the only opposition in the play, which relies on black-and-white contrasts. Stilling supports this idea:

\begin{abstract}
there can be no question but that Shakespeare felt tremendous poetic and emotional force in the juxtaposition of love and death and was determined to exploit both to the fullest. The nausea of bodily and psychological dissolution (...) is set against the beauty and strength of love (...). And the expected joy of the wedding day (...) is set ironically against the actual misery of loss. (1976:72-3)
\end{abstract}

Love and death are constantly intertwined, and so are sex and death, according to an age-long English tradition:

\begin{abstract}
The paradoxes and dualities inherent in the lovers' rhetoric are echoed in the violatory images that are deployed to mediate their deaths, and particularly Juliet's. She 'dies' twice in the play (...). Throughout these scenes Shakespeare plays on the erotic possibilities of Elizabethan English in which both the words 'kill' and particularly 'die' carried undertones of sexual intercourse and ecstasy. Death has 'lain' with Juliet and 'deflowered' her, we learn, and Death will henceforth be old Capulet's son-in-law. (Weis, 2009:29-30)
\end{abstract}

Thus, the deep significance of religious sacraments is permanently blended with the earthly manifestations of erotic attraction, human fallibility, character flaws, the governance of temperaments, common behaviour and basic (im)morality. In Champion's words, "Set in a world of conflicting human demands, this tragedy requires that human dignity be achieved without the guidance of assumed moral absolutes" (1977:61).

Towards the end of the play, as the Friar grows ever more cowardly, Juliet grows ever more brazen - a technique often used by Shakespeare (in Macbeth, for instance). When faced with her family's command that she should marry Paris (IV, 1), she seeks advice with the monk and, in case he can offer none, she is prepared to ask him to sanction her resolution to kill herself. In her dealing with her parents' imposition, she seems much more trenchant and honest than the friar. But we are left to wonder if this audacity is not just for show, since it would be impossible for a clergyman to knowingly condone suicide and Juliet would well know it. However, her strength shapes her character and, as Davis asserts, "resisting or contesting patriarchal authority allows a temporary move towards selfhood" (44). This is what Hermia also does in A Midsummer Night's Dream in comic mode.

Juliet's most surprising reaction in the play occurs when she is about to drink the potion that would make her numb. In a moment of doubt, she wonders: "What if it be a poison, which the friar / Subtly hath minister'd to have me dead, / Lest in this marriage he should be dishonour'd, / Because he married me before to Romeo? / I fear it is, and yet methinks it should not, / For he hath still been tried a holy man" (IV, 3, 23-28). This utterly disenchanted view testifies to her lack of any implicit trust in the Church, which stresses her Protestant, rather than Catholic bent. On the other hand, her intuition supports the theory according to which in Act V, Friar Laurence leaves her alone in the tomb hoping she would kill herself.

Surprisingly enough, the only sincere and truly Christian cue in the play seems to come from Paris, who exclaims, before allowing Juliet to withdraw with her "ghostly confessor": "God shield that I should disturb devotion!" (IV, 1, 41)

As far as cultural identity is concerned, nothing brands Romeo and Juliet as positively Italian. However, the very fact that Shakespeare chose Italian characters to write his emblematic play on unfettered love is telling in itself. As Sasha Roberts states, "uncontrolled sexual passion, often attributed to the hot climate, was considered an Italian characteristic; a stereotype intensified by the sensational accounts of Italian debauchery that proliferated in that period" (2003:120). She goes on to quote Roger Ascham, who wrote that on a nine-day trip to Venice he saw "more libertie to sinne than ever I heard tell of in our noble Citie of London in nine year". ${ }^{7}$

\footnotetext{
7 Ascham (1515-1568) in The Scholemaster (1570): Italy is sinful and a danger to the Englishman traveler: "Italianato è un diavolo incarnato".
} 
At least twenty-seven operas have been based on this play by Shakespeare, the earliest of which was either Johann Gottfried Schwanenberger's Romeo e Giulia (on a libretto by $J$. $R$. Sanseverino) or Georg Benda's Singspiel Romeo und Julie (on a libretto by Friedrich Wilhelm Gotter), both written in 1776. Twenty years later, Niccolò Antonio Zingarelli wrote his Giulietta e Romeo (1796), which has gone out of the regular repertoire. Winton Dean writes about it: "The music, again replete with prayers, is imperturbably platitudinous" (qtd. in Willier, 2002:133). This indicates that the religious aspect was not neglected in a work generated in a Catholic country at the end of the eighteenth century.

The first two opera adaptations to be written by well-known composers also belonged to Italians: Nicola Vaccai's Giulietta e Romeo (1825) and Vincenzo Bellini's I Capuleti e i Montecchi (1830). Their libretti were written by Felice Romani, who reworked the former to fit the latter in what Andrew Porter calls a "careful and thorough remodelling of an earlier work to suit Bellini's musical and dramatic ideas" (qtd. in Willier, 135). Osborne calls this double libretto taut and single-minded (1994:329). Sarah Lenton considers the characters to be single minded and stereotypical (2009:35). Dean is a singular voice among critics in considering that the two libretti are not identical, but quite different and even with different characters. He judges Vaccai's to be the better one (in Willier, 133).

In 1831, Berlioz revealed the fact that this libretto is not based on Shakespeare directly, but on his Italian sources ${ }^{8}$. In this Italian context, the Capuleti and Montecchi are rival political factions here - Guelphs and Ghibellines respectively - rather than Shakespeare's "Two households, both alike in dignity" (Prologue, 1), which obviously makes the Italian setting much more prominent. The issue of religion, however, is almost entirely suppressed in these two operas, since Lorenzo, according to the Italian play, is only Giulietta's physician and confidant and "Friar Laurence loses his tonsure and, as a medical man, substitutes for the Apothecary" (Orrey, 1969:101). Consequently, the two lovers are not even married! As Izzo remarks, the libretto focuses exclusively on the two protagonists (2009:14), marginalising the secondary characters and with them the religious undertones of the plot. However, in the end only Romeo kills himself. Giulietta dies of grief - much more appropriate behaviour for belcanto opera in general and for the nineteenth century in particular, as it abhorred violent death on stage. This ending thus absolves her of the deadly sin, illustrating a Catholic concern with Christian compliance.

In 1839, an entirely innovative work sees the light of day: Berlioz's dramatic symphony Roméo et Juliette. In love with Shakespeare, the French composer was aware that a great number of operas had already based their libretti on the star-crossed lovers' story, so he decided to anchor his opus in another genre - that of programmatic vocal-symphony music, on which Masson says Berlioz pondered his whole life (1952:185). Avoiding not so much the eloquence of his predecessors' characters as that of Shakespeare's, Berlioz decided to depict the two protagonists through the orchestra and built their voices from the tumult of this collective instrument. Thus, the strength of their love, the rush of their desire, the pangs of their heartbreak and sorrow are poignantly expressed through the means germane to music. However, their thoughts on faith and religion are forever silent in this work.

The text is signed by Émile Deschamps, and Andriot considers it to be mediocre and comment on Shakespeare's play in the manner of the ancient chorus (1987:54). But even if from a poetic point of view he is right, from that of choices, ideas and character features it proves to be rather interesting. This text preserves very little from the play - next to nothing, and almost only group scenes interpreted by the chorus who stands either for the Prologue Chorus or for the supporters of the Capulets and Montagues. Among the individual characters, the only ones who are given voices are

\footnotetext{
${ }^{8}$ The string of influence seems to be as follows: Giuseppe Maria Foppa's libretto for Zingarelli's Giulietta e Romeo (Milan 1796), itself relying on a play written by Luigi Scevola in 1818, inspired from Matteo Bandello's 1554 novella - a reworking of Luigi da Porto's 1530 tale Historia novellamente ritrovata di due nobili amanti, ultimately based on a fifteenth-century story by Masuccio Salernitano. Michael Collins (qtd. in Willier, 132) offers two other possible sources - a ballet dependent on both Foppa and Scevola - Le tombe di Verona, ossia Giulietta e Romeo, choreographed by Antonio Cherubini (Cremona ca. 1820) and Roméo et Juliette (1772) by Jean François Ducis, a notorious adapter of Shakespeare. On the other hand, Franca Cella claims that Foppa's sources were Gerolamo della Corte's Storie di Verona (qtd. in Weinstock, 251).
} 
Mercutio (in Queen Mab's Scherzetto) and Friar Laurence (in his Recitative and Aria placed after the death of the lovers).

But since everything before the final scene is omitted, so is the whole structure of actions and intentions that build up to his concluding discourse of self-defense. Nevertheless, this libretto, the shortest of all, is the only one that conveys the guilt of the monk. Unaware of his self-incrimination, Friar Laurence quotes Juliet's reproach (absent in Shakespeare's play, but equivalent to the doubts we have seen she expresses):

\section{LE PERE LAURENCE:}

'Only you', she cried, 'could have saved me!

There is nothing left for me but to die!'9

This libretto also respects Juliet's valour and her bold fearless choice of a masculine weapon for her suicide (the dagger), while decorously skipping the details of Romeo's womanly choice (poison). On the contrary, an ambiguous reference (to his ravished breast) insidiously suggests he too has stabbed himself:

\section{LE PERE LAURENCE:}

But Romeo, deceived in the funeral chamber,

Got there before me to die

Over the body of his beloved.

And almost as soon as she awoke,

Juliet, seeing

The death he carried in his ravished breast,

Armed herself with Romeo's blade

And passed into eternity

Just as I was arriving!

The friar still wants to present his act of marrying the two lovers to his advantage in an act of captatio benevolentiae:

I saw in it the salutary token

Of a future friendship between your two houses.

In a speech slightly reminiscent of Julius Caesar's rhetoric according to Appian, he subliminally implies his own victory. Deschamps's also thunders upon the families that the two deaths are God's punishment for their feud, deflecting attention for his own responsibility:

Capulets, Montagues! Come, see, touch

The hatred in your hearts, the insults in your mouths!

$\ldots$

God is punishing you where you love!

His chastisements, his vengeful lightning

Have the secret of our terrors!

Hear his thundering voice:

"So that on high my vengeance may forgive,

Forget your own furors!"

Moreover, Berlioz's Friar Laurence exceeds the audacity of his Elizabethan counterpart, pretending to know exactly what God means to tell the two families, as he is anointed and has God's grace through the sacrament of priesthood - an essential distinction between the Catholic and Protestant denominations. He accuses, he points fingers, he scolds from his high horse. In the middle of his ranting discourse, he slips his invocation that God should testify to the purity of his intentions, subtly seeing to it that it is not consciously perceived but subliminally assimilated. Last but not least, he presents himself as able to direct God's clemency towards the sinners who have gone astray:

${ }^{9}$ All the quotations from Deschamps are in my translation. 


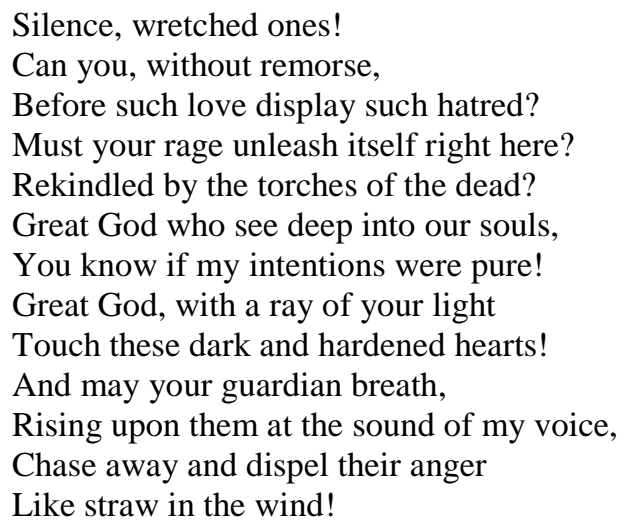

To a spectator or a reader that bears Shakespeare's play in mind (as Berlioz and Deschamps did), the monk's strategy is damning. However, to an audience that is confronted directly with this single appearance of this character in the dramatic symphony, Friar Laurence becomes an honest, luminous figure who has tried to save the lovers but failed. Crabbe proves this in his comment:

Apart from the Requiem and the Te Deum, ostensibly proclamations of Catholic faith, nearly all of Berlioz's major works contain religioso passages or movements which the composer felt to be inspired by religious feelings. Possibly this was for him sometimes simply a name for certain types of musical expression, though it is difficult, for instance, to feel that the composer of Romeo and Juliet did not believe in the type of humanitarian Christianity propounded by Friar Laurence in the finale. (1980:30) listeners.

However, Juliet's cry - "Only you could have helped me!" - is there to remind oblivious

In his masterpiece Roméo et Juliette (1867), Gounod, even if aware of his recent illustrious French precursor and his symphony, dares defy the long line of operas before it and surges as an entirely different instance.

As Saint-Saëns wrote, "There are two natures in Gounod's artistic persona: the Christian nature and the pagan nature, the seminary student and the boarder of the Ecole de Rome, the apostle and the minstrel" (1994:37, my translation).

The libretto signed by Jules Barbier and Michel Carré follows Shakespeare's play faithfully. As Huebner points out, they did not allow any other adaptation to come between the literary masterpiece and the opera (1994:173). He also astutely remarks that love forbidden for family reasons is a theme that Gounod had already tackled in Mireille, his opera inspired from Frederic Mistral's eponymous Provençal poem.

However, even if the libretto is faithful to the play, what is added is precisely the religious, Catholic dimension that the Bard's play lacks, but which looms large in Gounod's works, as he was a former seminary student.

Since the marriage is quintessential to the play, it takes place on stage, in front of the audience. All the vile suspicions that Shakespeare casts onto the monk are gone, and he performs the ceremony with piety and self-abasement:

\author{
FRIAR LAURENCE \\ O God who madest man in Thine own image ${ }^{10}$ \\ And of his flesh and blood \\ Created woman, and, joining her \\ To man in wedlock, \\ From Zion's summit consecrated \\ Their inseparable union! \\ Look with a favourable eye upon
}

\footnotetext{
${ }^{10}$ All quotations from this opera are from Barbier and Carré's libretto.
} 
Thy miserable creature

Who prostrates himself before Thee!

The whole scene is a prayer to God, and the bride and groom are prostrated:

ROMEO AND JULIET

Lord, we promise to obey Thy law. (...)

Lord, be Thou my support, be Thou my hope! (...)

Lord, from darkest sin it is Thou who dost protect us! (...)

Lord, deign to look down upon our love! (...)

O happiness unalloyed! O immense joy!

Heaven itself has received our loving vows!

God of goodness! God of mercy!

Be Thou blessed by two happy hearts!

The implicit submission of women sententiously pronounced by Friar Laurence in the play is reinterpreted here in the spirit of nineteenth century France, where the woman was empowered:

Ordain that the yoke of Thy handmaiden

May be a yoke of love and peace!

Juliet's economical metaphor of the heart is given an entirely new valence: "Let virtue be her wealth" - Friar Laurence prays.

Far from Shakespeare's mundane monk, who is ready to suspect carnal sin but is a stranger to true love, his equivalent in the opera perceives precisely this dimension of the lovers' attachment and, wishing them to beget children and grandchildren, prays that, "united in the life eternal", they should "come at last to the Kingdom of Heaven".

Condé concludes his article remarking that "Paradoxically, this opera of which it has been said, without erring much, that it is more bourgeois than Berlioz's Symphonie dramatique, ignores the final grand scene of the family reconciliation (whose motif had so strongly impressed a young Gounod in 1839) and it ends in the bliss of a double suicide" (1994:35, my translation), thus agreeing with Saint-Saëns's opinion that Gounod was half Christian, half pagan.

Indeed, too much in love to be able to live without each other, Romeo and Juliet commit suicide in the opera too. But, in an exquisite duet, they die singing "Lord, Lord, forgive us!" imploring God's absolution for their capital sin, which lends the opera a Christian dimension entirely absent from Shakespeare's play.

In 1907, the English composer Frederick Delius wrote an interesting opera - A Village Romeo and Juliet, whose libretto he and his wife Jelka based on the novella Romeo und Julia auf dem Dorfe written by the Swiss author Gottfried Keller at the end of the nineteenth century. The literary source has no direct connection to Shakespeare. Moved to a Germanic space and Protestant background, this is a story revolving around land property. The Dark Fiddler is the rightful owner of a disputed land, and Sali and Vrenchen, who live on it, have loved each other since childhood. After a complicated warp of disinheritance, they decide they cannot live a life of vagrancy and commit suicide by drowning. All trace of spirituality is gone. But the Protestant idea of working hard to make a living is gone too. All that is left is the Puritan leitmotif of predestination and doom.

The last well-known opera based on Shakespeare's play so far is Riccardo Zandonai's Giulietta e Romeo on a libretto signed by Arturo Rossato, which premiered in 1922. Like its other Italian predecessors, it relies less on Shakespeare than on his Italian sources going back as far as the fifteenth century. As Lanza-Tomasi remarks, 'Italian version' means 'melodramatic version' in which the dramatic fashioning of the characters is transferred upon the vocal archetypes of passion $(1984: 191)$. 
Since Friar Laurence is not a character in this opera, no wedding is mentioned. However, the question of marriage is quite ambiguous, which might be deliberate, since the two lovers seem to have an already old history of secret encounters in her chamber, which would be less than virtuous and quite sinful out of wedlock. In their Act I duet, Romeo sings: "The hatred between our families and fate / Will no longer be able to tear you apart from me. / In this life and even beyond death, / You are my wife, / I swear before God, my love!” (Rossato, 1929:24, my translation) Schmidgall asserts that the two are already married before the opera begins (1990:292), but it seems odd - to say the least - to swear to someone before God that she is your wife. In all probability, the present tense is here used for the future tense and this is Romeo's pledge to do... the right thing. But, as stated before, the confusion might be deliberate.

The religious aspect is therefore eliminated, although Zandonai wrote about twenty-five religious works (according to Alberto Petrolli's catalogue). Tonetti also points out that there are religious pages in some of his operas - "Nato è Gesù" in Grillo del focolare, the chorus "O figlie di Jerusalem" in Melenis and the chorus "Natal! Natal!" in I cavalieri di Ekebù (1984:311). But Giulietta $e$ Romeo is not among these operas.

However, at the end Romeo takes poison and Giulietta dies of grief at the loss of her love, which bears witness to the fact that a librettist and a composer, both Catholic, strive to absolve the female protagonist from the capital sin.

Romania has also made its contribution to the tortuous destiny of these musical adaptations. Romanian composer Roman Vlad wrote the music to Renato Castellani's famous 1954 film Giulietta e Romeo, which won the Golden Lion at the Venice Film Festival and was nominated for the best foreign film award by the National Board of Review, which also nominated Castellani for best director. The film contains interpolated scenes intended to establish the class system and Catholicism of Renaissance Verona, as well as the nature of the feud. Some of Castellani's changes have been criticised: these dialogues are often banal, while the Prince's appearances are presented as formal hearings, straining the spontaneity of Benvolio's defence of Romeo in the duel scene. In Rosenthal's opinion, Friar Laurence becomes "an irritating ditherer" (2007:213-14), but Pauline Kael claimed that Mervyn Johns's acting transformed the Friar from a tiresome presence into "a radiantly silly little man" (1991:639).

The visual element reigns supreme in cinema, and subsequently the friar's small cell becomes a sumptuous church. Ironically, the Franciscan habit - a brown full-length robe designed in the form of a cross and originally made of rough, unbleached, homespun wool - is turned into elegant Catholic priests' robes, quite inconsistent with the Franciscan vow of poverty (stressed in Shakespeare's play by the reference to the monks' bare feet).

Vlad's music, however, is quite important in creating the atmosphere of the film, as it draws on Catholic church music to illustrate the religious climate of mediaeval Italy - ironically, since the composer was not a Catholic.

The most universally famous adaptation of Shakespeare's play for the musical stage is Bernstein's West Side Story, with lyrics by Stephen Sondheim and choreography by Jerome Robbins, which is significant, since all three of them were American Jews. The musical premiered on Broadway in 1957. In 1947, Robbins approached Bernstein and Arthur Laurents about collaborating on a contemporary musical adaptation of Romeo. He proposed that the plot should focus on the conflict between an Irish Catholic family and a Jewish family living on the Lower East Side of Manhattan, during the Easter and Passover season. The libretto, therefore, was to be the most religionoriented version of all the adaptations. The modern-day Juliet was to be a survivor of the Holocaust emigrated from Israel; the conflict was to focus on the anti-Semitism of the Catholic "Jets" aimed at the Jewish "Emeralds". Bernstein wanted it to be an opera, but Robbins and Laurents rejected the suggestion. The project was referred to as "lyric theatre" and Laurents wrote a draft he called East Side Story. Once they saw it, they realised the theme had been tackled more than once in non-musical plays such as Anne Nichols's Abie's Irish Rose. When Laurents withdrew, they abandoned the project and forgot about it for almost five years.

In the 1950's, gang violence had spiked out of all proportion and people were terrified. It was a newspaper article that Laurents and Bernstein claimed inspired them to turn the conflict to juvenile 
delinquent gangs. Bernstein suggested they should set the action in Los Angeles, but Laurents felt more familiar with Puerto Ricans and Harlem. Robbins was thrilled at the idea of a musical with a Latino beat. Therefore, the Jewish dimension of the work written by three Jews disappeared altogether in the end, as did any religious undertones.

An exotic notion to New York gangs, the official marriage disappears. With it, Friar Laurence and the incongruous potion, difficult to "swallow" by a mid-twentieth century audience. However, the hurricane-like tumult of teenage love is still very vivid and, as Simeone intuits, "This is perhaps the reason for the show's continuing success today: half a century later, the precise circumstances that inspired it may have changed, but the value of human life - and the simple power of love - have not" (2009:6). Thus, doing perfectly without a priest, the two lovers - Tony and Maria - exchange vows, a mixture between the common vows of the Catholic ritual and their own, personal pledges.

TONY \& MARIA: I, Anton/ Maria, take thee, Maria/ Anton

For richer, for poorer ... (etc.)

Till death do us part.

With this ring, I thee wed. (...)

Make of our lives one life,

Day after day, one life.

Now it begins, now we start -

One hand, one heart;

Even death won't part us now.

Musically, the "Marriage Scene" is imbued with solemn sobriety, making up in sound what the context lacks in sacredness. But this may not be the only religious whiff that finds its way into the score. Bernstein's former assistant, Jack Gottlieb, dedicated a chapter to Bernstein in his Funny, It Doesn't Sound Jewish:

Gottlieb examined specific influences from synagogue music and Yiddish songs (...) and (...) demonstrates the similarity between a traditional shofar call and the three-note 'shofar' figure in West Side Story. (...) Gottlieb also describes ambiguities between major and minor thirds as being characteristic of synagogue music, and of early Yiddish secular song. In various forms, either in melodic lines or in harmonies, this is another stylistic marker in West Side Story (...).

There are other parallels with synagogue music: the shape of the benediction (...) finds a clear echo in 'Maria' (...); another is the instrumental underscoring (...) in 'One Hand, One Heart', similar to the 'Call to the Torah' quoted by Gottlieb. (Simeone, 83)

However, Bernstein's music, which also claims Western legacies (Beethoven, Wagner or Stravinsky), does not sound derivative. It is highly personal and genuine.

If the music may reflect sacred Jewish ancestry, at the level of ideas the issue of religion is absent, since both gangs are Catholic (Puerto Rican Sharks and Polish Jets) and neither is in any way concerned with spirituality. What replaces this central topic is the theme of cultural identity, which is worth dying for. In the end, Tony - the American Romeo - is murdered, and Maria, his sweetheart, survives. Post-war America is a place and age in which no one dies for love anymore.

A staggering number of musical works have been inspired from Shakespeare's play, pertaining to various genres, cultural spaces and ages: Filippo Marchetti's opera Romeo e Giulietta (1865), Henry Hugh Pearson's overture for orchestra Romeo and Juliet (1865), Tchaikovsky's overture-fantasy Ромео и Джульетта (1869), Johan Svendsen's fantasy Romeo og Julie (1876), Wilhelm Stenhammar's incidental music to Romeo och Julia (1922), Prokofiev's ballet (1935), Heinrich Sutermeister's opera Romeo und Julia (1940), Dmitry Kabalevsky's incidental music to the play (1956) and many more. As Schmidgall puts it, "the play seems heaven-sent as an operatic vehicle" (293). It is interesting to remark that the works that attained the greatest strength of expression are those that dealt with it abstractly, with the least resort to text (Berlioz, Tchaikovsky and Prokofiev). Among the operas, the only notable exception is, perhaps, Gounod's. Music thus 
replaces the grandeur and force of Shakespeare's text, for it is daunting to rival with the miraculous fabric of his words. As Schmidgall laments, "conspicuous failure to encompass fully the various elements of Shakespeare's tragedy of star-crossed love has been the unfailing rule since the competition began in 1776 with a Leipzig Romeo e Giulia ${ }^{l l "}$ (293).

One can only wonder what Verdi might have succeeded if he had turned this play into an opera. Along with King Lear, The Tempest and many other Shakespearean titles, Romeo and Juliet was one of the literary sources that he pined for all his life and dreamt of adapting:

And yet Romeo! What a tempting subject! I envisage the work, I live this work. It is there in my head. Background: hatred, bloody strife between Montagues and Capulets. Foreground: the tragic love of the two children. Then there's the entire comic side, which Gounod ignored. I would have wanted to create a more spirited work with greater contrasts, not a long duet. (Verdi qtd. in Schmigdall, 293)

And from his Macbeth and Othello we know that he captured Shakespearean tragedy like no one else, while his roar of laughter in Falstaff assures us his Mercutio and Nurse would have been unforgettable.

The abundance of opera adaptations of Romeo and Juliet introduces us to another kind of Protean Shakespeare. In Othello, Iago swears "By Janus!"12 (I, 1, 33), this Roman god being usually depicted with two faces, but initially with four. Many of Shakespeare's characters are two-faced (Friar Laurence among them), most of them have extremely complex, multi-layered personalities. And each play is a kaleidoscope - each time you look at it from a different angle you see a new, different image. Meanings and significances shift and change before our eyes, just as Proteus is the god of elusive sea change. And the variety of musical works created to adapt the text come to enhance this eversurprising richness. Proteus could foretell the future, and the ceaseless influx of adaptations foretell that Shakespeare is immortal and that mankind will still commemorate him four hundred years from now.

\section{Works Cited:}

Andriot, P. 1987. Berlioz - Les Combats d'un romantique. Lyon: Albert Guillot.

Barbier, J and Carré, M. 1867. Roméo et Juliette. Libretto. English translation by Joseph Allen, 1969. http://www.murashev.com/opera/Rom\%C3\%A9o_et_Juliette_libretto_French_English. Retrieved on 26.03.2016.

Bolter, Jay David \& Richard Grusin. 2000. Remediation. Understanding New Media. Cambridge, Massachusetts, London: MIT Press.

Carroll, W. C. 2001. "Language and Sexuality in Shakespeare." In: Alexander, Catherine M. S. and Wells, Stanley (eds.), Shakespeare and Sexuality. Cambridge: Cambridge University Press, 14-34.

Champion, L. S. 1977. Tragic Patterns in Jacobean and Caroline Drama. Knoxville: University of Tennessee Press.

Condé, G. 1994. "Roméo et Juliette ou les couleurs de la nuit." In: Roméo et Juliette, programme, Théâtre du Capitole de Toulouse. Ivry-sur-Sène: Imprimerie Jourdan, 19-35.

Crabbe, J. 1980. Hector Berlioz - Rational Romantic. London: Kahn \& Averill.

Davis, L. 2001. "Death and Desire in Romeo and Juliet." In: Alexander, Catherine M. S. and Wells, Stanley (eds.), Shakespeare and Sexuality. Cambridge: Cambridge University Press, 35-51.

Deschamps, E. 1839. Roméo et Juliette. Libretto. <http://www.hberlioz.com/Libretti/Romeo.htm>. Retrieved on 25.03.2016.

Giulietta e Romeo. Director. Renato Castellani. Performers. Laurence Harvey, Susan Shentall, Mervyn Johns. 1954. DVD. Ermitage Cinema, 2008.

\footnotetext{
${ }^{11}$ Schwanenberger's opera. The exact date of the premiere is not recorded. The premiere of Benda's Singspiel took place in Gotha on 25 September of the same year 1776, so Schwanenberger's may well be the first opera adaptation of the play.

12 In archaic Roman mythology, Janus was the god of gates, doorways, beginnings and endings (therefore passages).
} 
Greenblatt, S. 2005. Will in the World. How Shakespeare Became Shakespeare. London: Pimlico.

Huebner, S. 1994. Les Opéras de Charles Gounod. Arles: Actes Sud.

Izzo, F. 2009. “And Bellini Went to Venice.” In: I Capuleti e i Montecchi-Performance Programme. London: The Royal Opera, 11-16.

Kael, P. 1991. 5001 Nights at the Movies. Holt Paperbacks. New York: Picador.

Lanza-Tomasi, G. 1984. "Giulietta e Romeo." In: Chiesa, Renato (ed.), Riccardo Zandonai. Milano: Edizioni Unicopli, 189-201.

Lenton, S. 2009. “No Mercutio, no Hermit, no Balcony Scene, no Shakespeare, no Anything!” In: I Capuleti e i Montecchi-Performance Programme. London: The Royal Opera.

Masson, P-M. 1952. "Hector Berlioz et l'esthétique française du XVIII siècle." In: Mélanges d'esthétique et de science de l'art offerts à Étienne Souriau, professeur à la Sorbonne, par ses collègues, ses amis et ses disciples. Paris: Librairie Nizet.

Orrey, L. 1969. Bellini. The Master Musicians Series (edited by Sir Jack Westrup). London: J. M. Dent and Sons Ltd. / New York: Farrar, Strauss and Giroux, Inc.

Osborne, C. 1994. The Bel Canto Operas of Rossini, Donizetti and Bellini. London, Auckland, Melbourne, Singapore and Toronto: Methuen.

Roberts, S. 2003. "Reading Shakespeare's Tragedies of Love: Romeo and Juliet, Othello, and Antony and Cleopatra in Early Modern England.” In: Dutton, Richard \& Howard, Jean E. (eds.), A Companion to Shakespeare's Works, Volume I: The Tragedies. Malden, Oxford, Victoria \& Berlin: Blackwell Publishing, 108-133.

Rosenthal, D. 2007. BFI Screen Guides. London: British Film Institute.

Rossato, A. 1929. Giulietta e Romeo. Libretto. Milano: G. Ricordi e C.

Schmidgall, G. 1990. Shakespeare and Opera. New York \& Oxford: Oxford University Press.

Saint-Saëns, C. 1994. "Charles Gounod, esquisse de portrait." In: Roméo et Juliette, programme, Théâtre du Capitole de Toulouse. Ivry-sur-Sène: Imprimerie Jourdan, 37-39.

Shakespeare, W. 2008. Romeo and Juliet. The Oxford Shakespeare. Oxford World's Classics. Stanley Wells (gen. ed.). Jill L. Levenson (ed.). Oxford: Oxford University Press.

Simeone, N. 2009. Leonard Berstein: West Side Story. Farnham \& Burlington: Ashgate.

Sondheim, S. 1957. West Side Story. Libretto. <http://www.allmusicals.com/w/westsidestory.htm>. Retrieved on 27.03.2016.

Stilling, R. 1976. Love and Death in Renaissance Tragedy. Baton Rouge: Louisiana State University Press.

Tonetti, O. 1984. "Le musiche religiose." In: Chiesa, Renato (ed.), Riccardo Zandonai. Milano: Edizioni Unicopli, 311-18.

Weinstock, H. 1972. Vincenzo Bellini. His Life and His Operas. London: Weidenfeld and Nicolson.

Weis, R. 2009. "From another Angle: Shakespeare and the Tale." In: I Capuleti e i Montecchi-Performance Programme. London: The Royal Opera.

Willier, S. A. 2002. Vincenzo Bellini. A Guide to Research. New York and London: Routledge. 